\title{
Imperative Role of Photovoltaic and Concentrating Solar Power Technologies towards Renewable Energy Generation
}

\author{
Vinod Kumar Sharma $\left(\mathbb{D},{ }^{1}\right.$ Rajesh Singh $\mathbb{D}^{2},{ }^{2}$ Anita Gehlot $\mathbb{D}^{2},{ }^{2}$ Dharam Buddhi, ${ }^{2}$ \\ Simone Braccio $\mathbb{D}^{,}{ }^{3}$ Neeraj Priyadarshi $\mathbb{D},{ }^{4}$ and Baseem Khan $\mathbb{D}^{5}$ \\ ${ }^{1}$ Department of Energy Technologies, Division of Bioenergy, Biorefinery and Green Chemistry, ENEA Research Centre Trisaia, \\ 75026 Rotondella MT, Italy \\ ${ }^{2}$ Division of Research \& Innovation, Uttaranchal University, Uttarakhand, 248007, Dehradun, India \\ ${ }^{3}$ Polytechnic of Bari, Italy \\ ${ }^{4}$ CTiF Global Capsule, Dept. of Business Development and Technology, Aarhus University, Herning 7400, Denmark \\ ${ }^{5}$ Department of Electrical and Computer Engineering, Hawassa University, Hawassa, Ethiopia 05 \\ Correspondence should be addressed to Baseem Khan; baseem.khan04@gmail.com
}

Received 2 December 2021; Revised 12 January 2022; Accepted 19 January 2022; Published 29 January 2022

Academic Editor: Amin Shahsavar

Copyright (C) 2022 Vinod Kumar Sharma et al. This is an open access article distributed under the Creative Commons Attribution License, which permits unrestricted use, distribution, and reproduction in any medium, provided the original work is properly cited.

\begin{abstract}
The United Nations Development Programme (UNDP) 2030 agenda illustrates the requirement of expanding infrastructure and advancing technology for delivering modern and sustainable energy services for all in developing countries. Moreover, UNDP also set a goal of increasing the renewable energy share in the global energy. Renewable energy resources are eco-friendly and widely available resources from nature for generating energy. Geothermal energy, wind energy, solar energy, tidal energy, and biomass energy are renewable energy sources. Solar energy is one of the renewable energy generation approaches that harvests energy widely from sun radiation. Photovoltaic (PV) and concentrating solar power (CSP) are the primary technologies to capture solar energy. This study presents the significance of utilizing solar energy for electricity generation globally using PV and CSP technologies. Furthermore, the distinct energy capturing and storing mechanisms of PV and CSP technologies are presented in detail. This article presents the significance and implementation of thermal energy storage for storing energy obtained through CSP technology. Finally, the study presents a considerable gap between PV and CSP in terms of development with future trends.
\end{abstract}

\section{Introduction}

Over many years, momentum in establishing worldwide renewable energy sources has intensified. Renewable energies tend to be significant in the context of sustainable energy generation $[1,2]$, and the production of renewable resources worldwide, estimated at 20 percent, is primarily made up of biomass [3] and hydroelectricity [4]. The dramatic prospects for critical trends for the succeeding 60-70 years, assuming a "business as usual" behavior correlated with stable progress and demographic perspective for the southern and northern countries, embody profound transformation which is clearly shown in Figure 1.
Figures 2(a) and 2(b) present the statistical data regarding the anticipation rise in electricity demand. Moreover, the reduction of proven oil supplies, the prefoliation of nuclear plant safety like danger of nuclear waste accumulation, the spike of carbon dioxide concentration in the environment, etc. are the critical concerns of the next century (Figure 3). However, the fact remains that such innovations are not able to adapt to the need for increased power generation, environmental conservation, and a potential decline in the usage of coal and oil. As long as environmental pollution is related, renewable energy is crucial for reducing pollution in a sustainable manner $[7,8]$. It has been anticipated that every billion kilowatt-hours of renewable energy will cut 


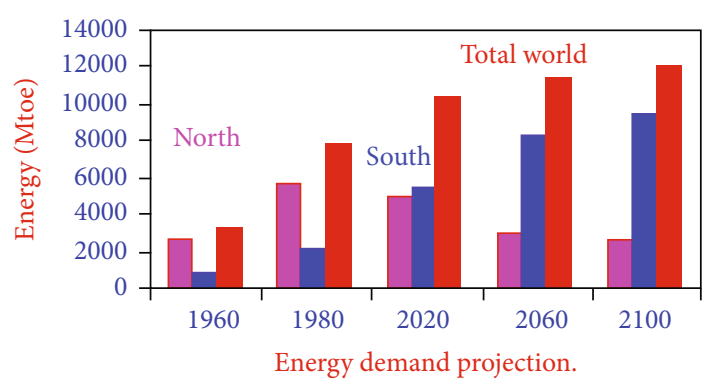

Figure 1: Energy demand projection (1960-2100) [5].

down sulfur emissions by 10,000 tonnes, particulate emissions by 2,000 tonnes, and carbon emissions by more than 200,000 tonnes [9]. There is an immediate need to build alternative energy sources that are environmentally sustainable. In spite of the above, it is of extreme significance that precise assessments are paid to appropriate measures such as a substantial reduction in energy use by the usage of alternative energy sources, energy conservation measures, and the combination of various types of energy. It should be pointed out that the reduction of energy demand is a daunting task, especially in terms of developing countries' needs, as it is intrinsically hard to operate in this field without an adverse effect on the development of the economy.

In 2017, ambient carbon dioxide levels were 406.5 parts per million, up $2.3 \mathrm{ppm}$ relative to last year. The second hottest high was last year, just 0.99 Celsius in 2016, above the average of 1951-80 [11]. It is suggested that larger government supplies for clean energy sources would help to offset the more than 60 percent growth in world electricity demand over the midterm and quickly cross the coal divide in the United States, EU, China, India, and Mexico. A study [12] is carried out to optimize the heliostat layout in central receiver solar power plants in order to obtain optimum heliostat field efficiency using genetic algorithm, and the result concludes that increasing the tower height and decreasing the heliostat height by 7.7 and 19.5 percent, respectively, increase the total efficiency of the field by nearly $4 \%$ while decreasing the total area of heliostats by $17 \%$. Innovative coolant tube layouts are developed and numerically modelled to achieve maximal exergy and energy efficiencies of photovoltaic-thermal (PV-T) systems [13]. Energy and exergy analyses of a photovoltaic-thermal system with wavy tubes are explored numerically using different coolant fluids to build a more efficient water-cooled photovoltaic-thermal system [14].

The contribution of the study is as follows:

(i) The overview and significance of solar energy are presented with statistics

(ii) The distinct types and mechanisms of photovoltaic (PV) and concentrated solar power (CSP) are presented

(iii) The implementation of thermal energy storage for storing the energy obtained through the CSP is addressed (iv) A considerable gap between the PV and CSP technology is presented for future enhancement

The structure of the study is as follows: Section 2 covers the overview of solar energy and the importance of PV and CSP technologies for harvesting solar energy. Section 3 covers the concept of thermal energy storage for storing the energy obtained by CSP. Section 4 provides the considerable gap of development between PV and CSP, and the final section concludes the article.

\section{Solar Energy}

Solar power promises to be the primary technology for the transition to a decarbonized supply of energy among the numerous renewable energy sources, which can be installed almost throughout the world. The efficiency of the photovoltaic (PV) system is directly proportional to solar energy [15-17]. Many countries identify that renewables and energy conservation solutions are chosen to be a functional approach for combating coal usage. Solar resources are vast in Europe and worldwide, and a 98-gigawatt solar power plant is the highest power capacity built-in 2017 [18]. It is indeed worth remembering that, in 2017, a gross amount of USD 279.8 billion was apportioned to all renewables globally. The energy sector earned $\$ 2.5$ billion on public markets in 2017, a spike of $\$ 1$ billion in 2016 [19]. Across several energy scenarios, solar energy has been viewed as a critical factor.

The utilization of solar energy has split into two significant technologies based on solar radiation harvesting and transforming into electricity [20]. The technologies are solar photovoltaic (PV) and concentrated solar power (CSP) technology. The CSP enhances solar energy density and also provides both electricity and thermal power. On the other hand, PV is the only technology that provides flexibility or even lowers future costs; regardless of how fast the electricity prices are rising, in the future, solar power by both photovoltaic (PV) and concentrated solar power (CSP) seems to be a successful mechanism not only to fulfill the need for electricity in the globe but also to satisfy the demand for the depletion of fossil fuels from other sources. Meanwhile, numerous future clean energy systems are only photovoltaic technology that has a larger potential to prevent carbon emissions and tackle energy problems in the future [21]. "Power for World," an exciting initiative to encourage and provide electricity to more than a billion people in impoverished developed world countries, was initiated by Dr. Wolfgang Palz [22]. The industry has been abandoned because a photovoltaic plant with a total capacity of $10 \mathrm{GW}$ is adequate to fulfill the minimum requirement of $10 \mathrm{Wp}$ per person for the poorest inhabitants of the earth.

2.1. Photovoltaic $(P V)$. As is the case today, $\mathrm{PV}$ is well accepted by most developed countries in the world. Several nations economically powerful sufficient, such as China, the United States, Japan, European countries, and India, have already made substantial investments in the growth of this specific field through their national programs [23]. 


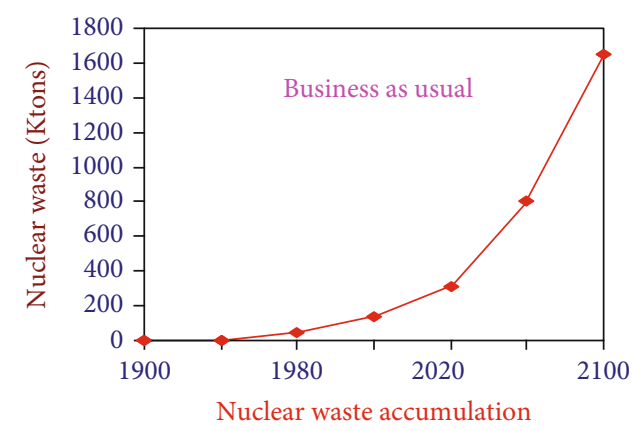

(a)

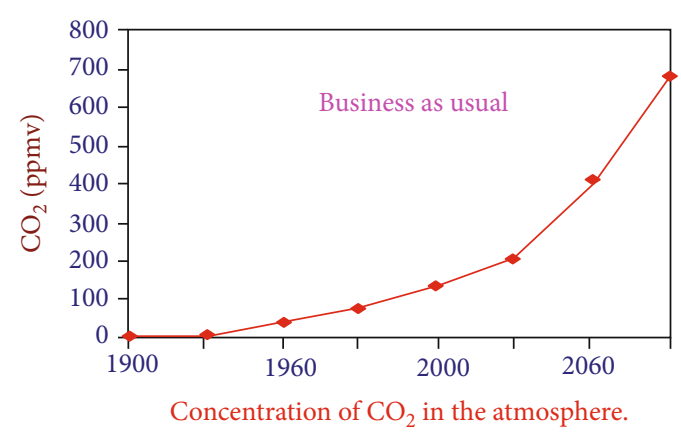

(b)

Figure 2: (a) Nuclear waste accumulation [6]. (b) Amount of $\mathrm{CO}_{2}$ concentration level [6].

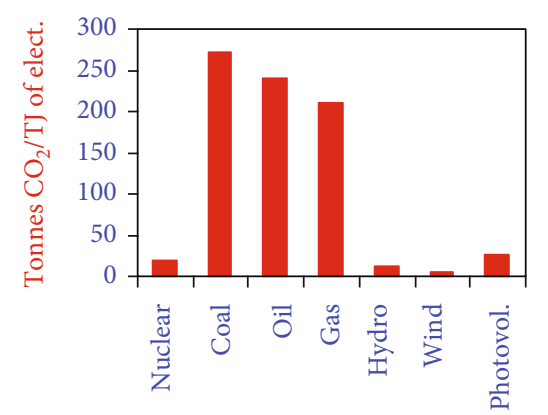

$\mathrm{CO}_{2}$ emitted by different energy sources.

Figure 3: $\mathrm{CO}_{2}$ emission from different energy sources [10]

The PV industry in the world has seen significant innovations. It is indeed noteworthy that photovoltaic, with builtin remote and central power stations generating hundreds of megawatts, is a technology that has already proven its reliability and is quite promising for the production of electrical energy on a global scale [24, 25]. The year 2019 was yet another streak year for the solar photovoltaic (PV) industry; about $60 \mathrm{GWp}$ of new solar PV installations was installed throughout the year. Figure 4 demonstrates that by the end of the year, the global total deployed PV capacity is equivalent to $632.4 \mathrm{GW}$ (gigawatt), and in 2019, the global cumulative solar capacity amounted to $633.7 \mathrm{GW}$ and with 116.9 GW of new PV capacity installed in the same year [26]. Midterm projections for global combined PV capacity by 2020 increase from $600 \mathrm{GWp}$ to $700 \mathrm{GWp}$, relying on the policy scenario. It is to be noted that the cumulative installed capacity of photovoltaic energy in 2019 in the European Union is mounted to be $134 \mathrm{GW}$. In contrast, it is expected that the same will be increasing to $370 \mathrm{GW}$ in 2030 and up to $1051 \mathrm{GW}$ in 2050.

In the foreseeable future, the European PV Technology and Innovation Platform (ETIP PV) benchmark scenario predicts that the global combined PV capacity will be about $9,000 \mathrm{GWp}$ by 2050 [27]. Considering the International Energy Agency (IEA) demand growth scenario, this power will produce around one-third of the world's annual energy use, considering the International Energy Agency (IEA) demand growth scenario.
The main pillars of photovoltaics are divided into three categories: PV fabrication technologies, PV system technologies, and advanced services to industries [26], which are shown in Figure 5. Crystalline silicon-based (c-Si) modules currently have more than $90 \%$ market share and will be the predominant PV platform in the future [29]. In multijunction methods, the incorporation of layers of distinct materials to the roof of silicon might increasingly boost quality. The significant benefit of silicon-based PV modules is that the critical raw material, silicon, is the second most abundant (after oxygen) in the earth's crust [30]. Many PV cells are composed of silicon, refined, and filtered from silicon dioxide, which is sand. Very few thin-film products are available in the market, which is the amalgamation of copper indium gallium selenide (CIGS) and cadmium telluride $(\mathrm{CdTe})$ [31].

However, thin-film technologies also weakened their comparative benefit over c-Si modules as silicon is now plentiful and very affordable which are illustrated in Figure 6(b). Thin films include rare elements such as indium and tellurium, which may be inconvenient if the production volumes were to escalate ten or a hundred times as anticipated by potential expansion [32]. Tellurium is almost as rare as platinum or copper, while silicon is about 60 million times more abundant than tellurium. First Solar is undoubtedly among the ten biggest PV module producers in the world, the only thin filmmaker [33]. Other PV technologies, such as organic or dye-sensitized cells, are also available but are still in the testing or demonstration process. They have a challenge with low efficiency and fast degradation in outdoor conditions, and it is not likely that they will ever be able to compete on a large scale with c-Si modules [34]. As of today, $\mathrm{PV}$ is well recognized by most of the industrialized countries in the world.

In 2015 , solar energy attracted $56 \%$ of all new renewable energy investments or USD 161 billion [35]. Private sector interest in renewables is picking up but accelerating that interest will need a significant increase in concessional finance. The critical factor behind this accelerated growth is the drastic price decline of the solar PV modules. In nominal terms, the recent $\mathrm{PV}$ module price, $0.40-0.50 \mathrm{USD} / \mathrm{Wp}$, is just 10 percent of the cost in 2008, and the price of the module will dip below $\$ 0.30 / \mathrm{Wp}$, according to IHS Markit 
PV installtion

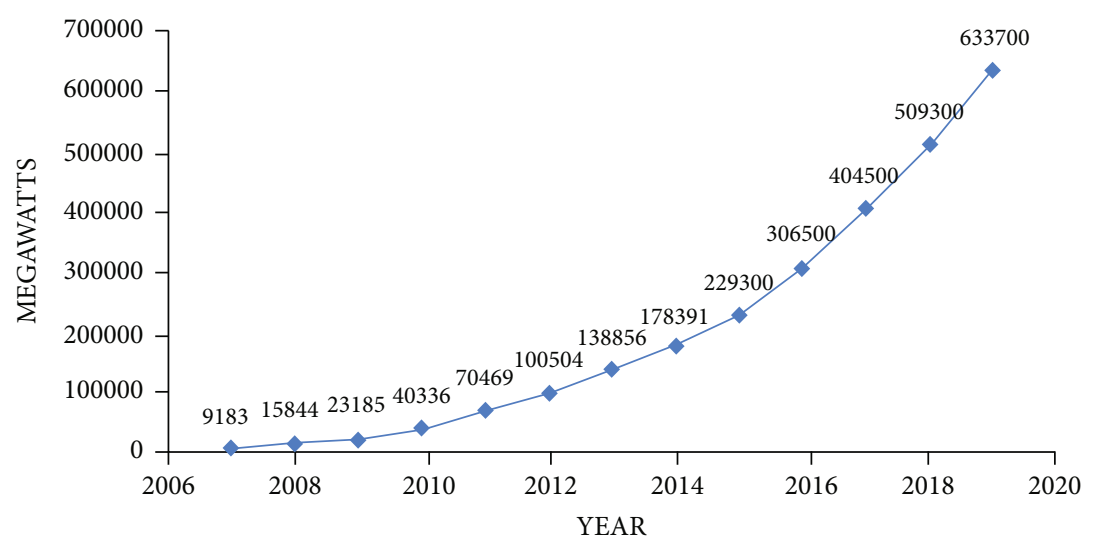

Figure 4: PV installations from 2000 to 2019 [28].

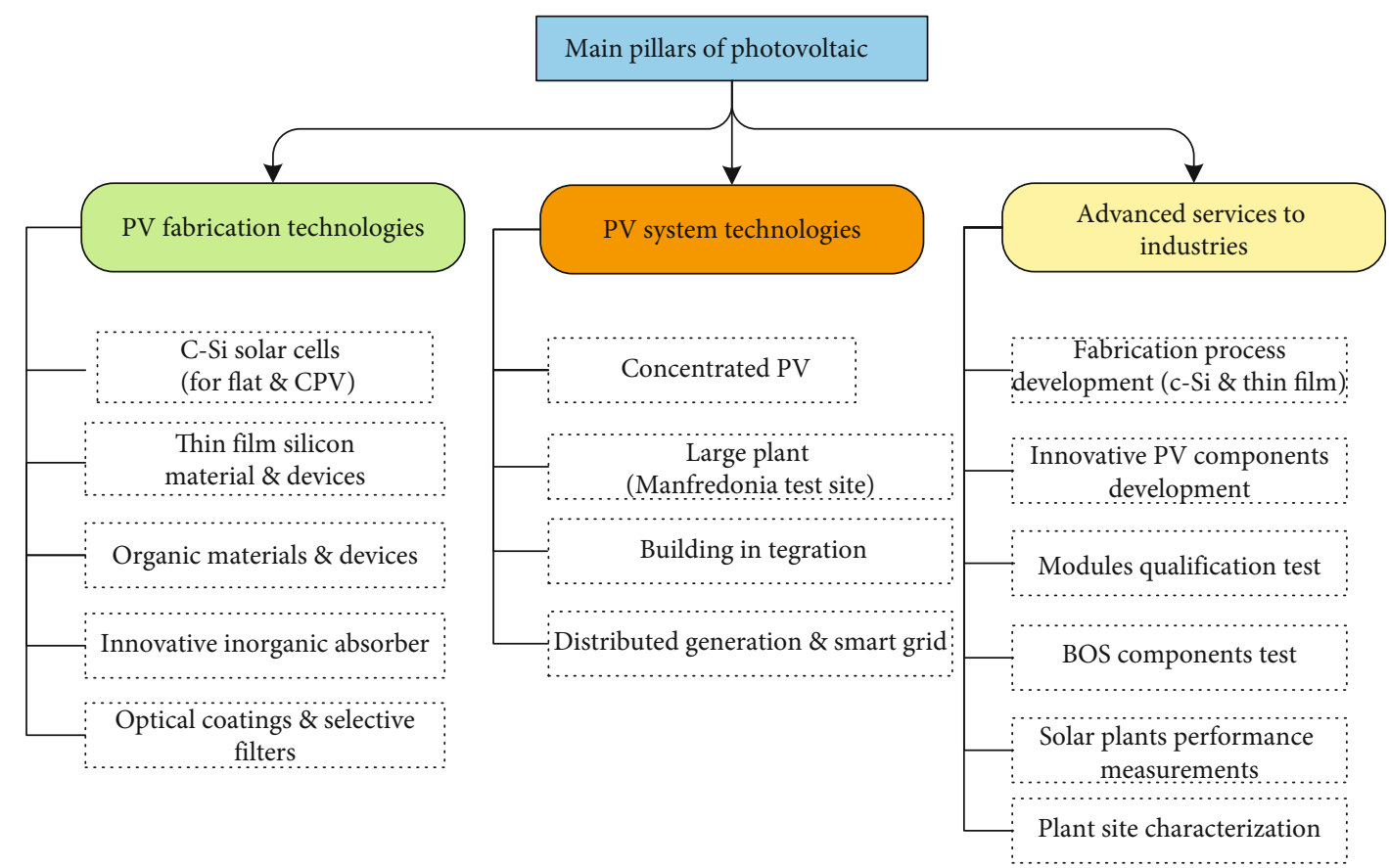

FIGURE 5: Main pillars of photovoltaics.

by 2020 [36]. ETIP PV will suggest a long-term basis scenario where the module's price is down to USD $0.10 / \mathrm{Wp}$ by 2050 [27].

In contrast to the modules, the PV system mounted contains components such as the Balance of System (BoS) inverters, wires, assembly, and construction structures. The contribution of the BoS cost in overall PV system capital (CAPEX) depends on the scale of the system. Still, typically less than half of it is utilized in large ground installations on competitive markets such as India [37]. The photovoltaic industry is effectively a semiconductor industry, where volume growth immediately reduces cost. The price of photovoltaic modules traditionally dropped by $20-25 \%$ each time the total installed capacity in the world doubled [38]. More effective use of materials, efficient processing methods, and enhanced efficiency of solar cells are the main determinants.

The average performance of PV modules is approximately around 16 percent and is expected to grow to 30 percent by 2050. Few commercial modules achieved 23 percent efficiency [39]. Best business modules now achieve a productivity of 23 percent. The automatic improvement in productivity lowers the PV CAPEX because about half the BoS cost is connected to the field. Better efficiency ensures that the PV modules use a smaller region every time. Best commercial modules already reach 23 percent efficiency which is shown in Figure 6. Increasing the efficiency drastically decreases the PV CAPEX because half of the BoS cost is area related. Better efficiency always means a smaller area required for the PV modules. 
A SCIENCE FED TECHNOLOGY

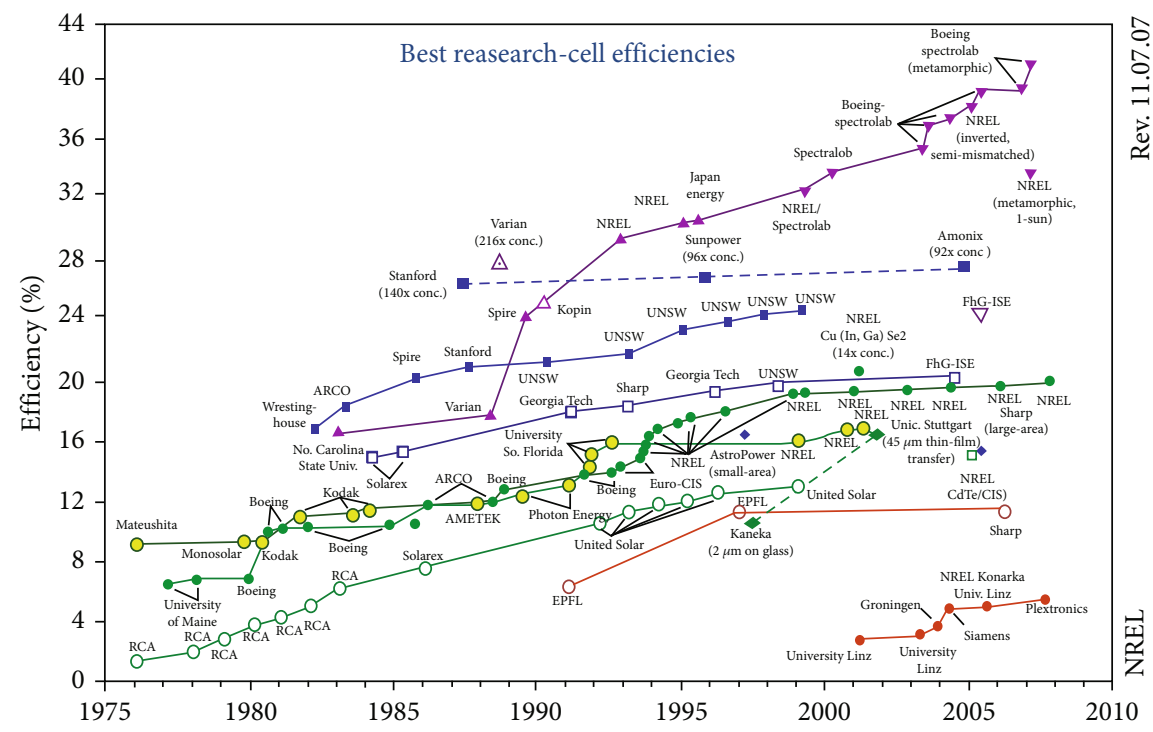

Multijunction Concentrators

Thin-Film Technologies

v Three-junction (2-terminal, monolithic)

A Two-junction (2-terminal, monolithic)

- $\mathrm{Cu}(\mathrm{In}, \mathrm{Ga}) \mathrm{Se} 2$

o CdTe

Amorphous SI:H (Sttabilized)

- Nono-, micro-, poly-Si

Single-Junction GaA

$\square$ Multijunction polycrystalline

$\triangle$ Concentrator

$\nabla$ Thin film

Crystalline Si Cells

- Single crystal

$\square$ Multicrystalline

Emerging PV

O Dye-sensitized cells

Organic cells

(various technologies)

- Thick Si film

(a)

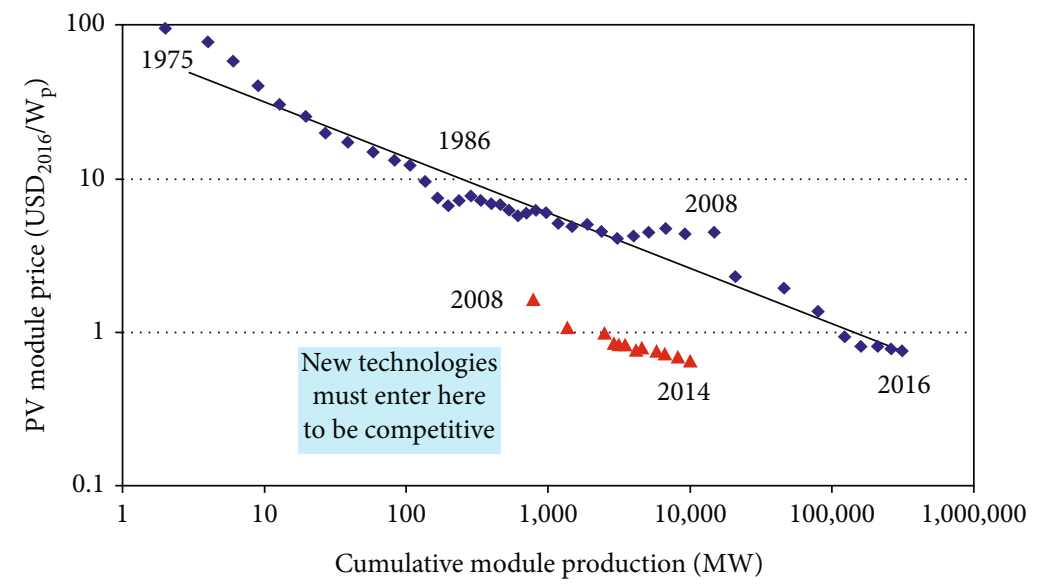

- Crystalline silicon

- FC CdTw thin film

(b)

Figure 6: Continued. 


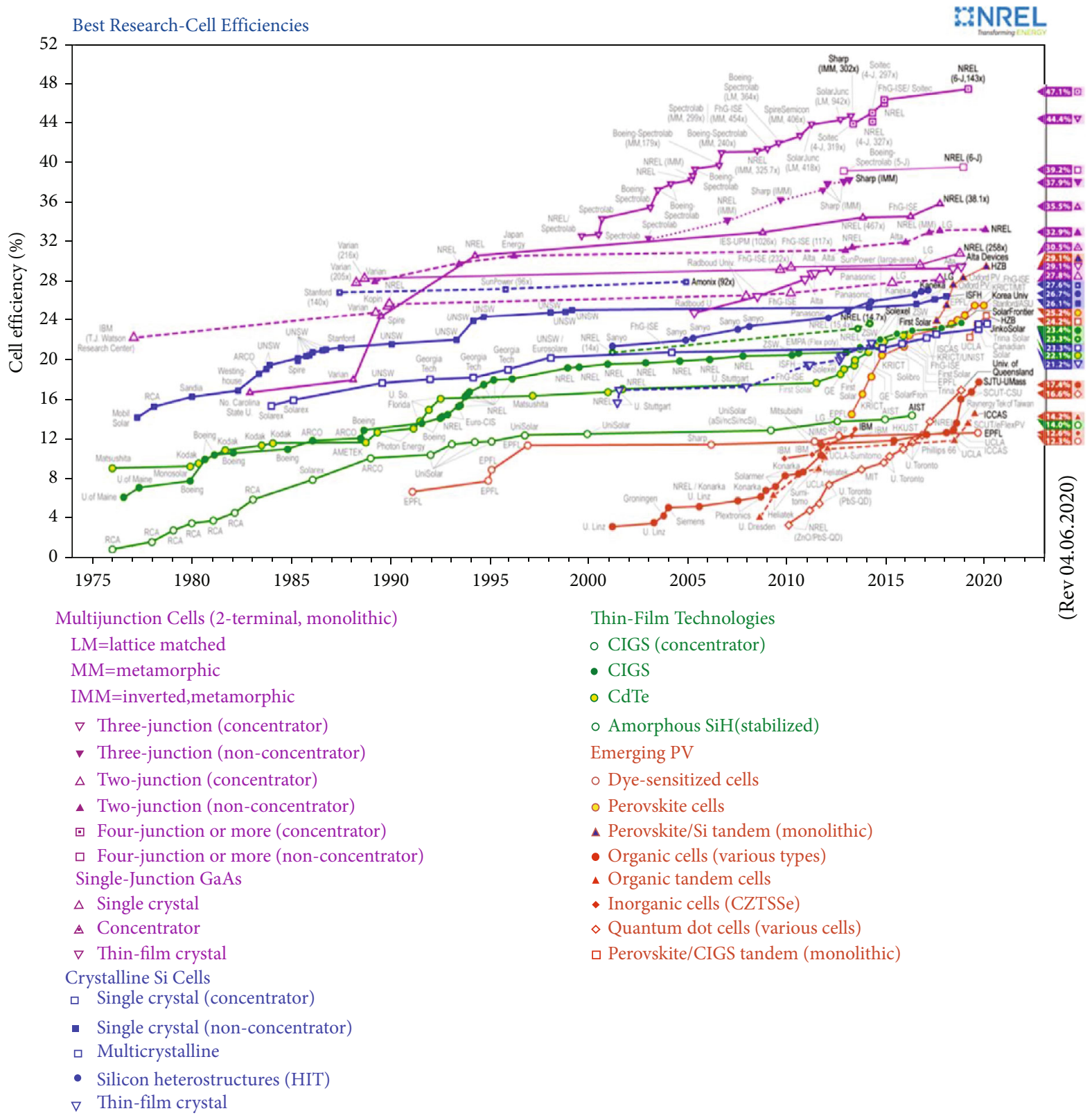

(c)

FIgure 6: (a) The efficiency of materials. (b) Production and price relation. (c) The efficacy of cells [40].

In a climate zone, average temperatures have no significant effect on the output of solar panels. In fact, in more excellent conditions, solar panels are generally marginally more effective at generating electricity. If we reside in a cooler climate, you just get enough sunlight while the solar panels are working only a step farther north. Anyway, the terrific PV capacity growth was encouraged by reward mechanisms. According to the majority experts, grid parity can be attained before 2020 in most implementations and the early ' 20 s in the remaining [41]. Complete form for consumer product (on-grid/off-grid) systems includes clocks, calculators, toys, greenhouse and production bunkers, residential applications, and electrical power plants. From $0.01 \mathrm{~W}$ up to $100 \mathrm{MW}$, residential applications are prevail- ing. Further drastic technical advances will lead to accurate market changes such as high-efficiency multilayers, quantum dots, and nanotubes and nanowires.

PV manufacturing is fundamentally a semiconductor industry, where the spike in production significantly reduces costs [42]. The average price of European crystalline silicon modules in 2017 dropped by $14 \%$ and is projected to fall by a further $15 \%$ in 2018 which has doubled; the pricing of PV modules has dropped 20-25 percent [43]. Other key factors are a more productive use of materials, more robust production practices, and better solar cell performance. Striking decrements in PV module cost is increasing BOS cost-share: from $30 \%$ to today's $50 \%$. As for BOS cost decrement, perspectives are mainly linked to scale effects, but for 
inverters ( $10 \%$ cost-share), average prices went down by $17 \%$ from 1990 to 2008 , primarily due to efficiency increase (from $90 \%$ to $98 \%$ ) [44]. Cutting down dangerous air pollution and diversifying energy supplies for a better source of safety may undoubtedly play a similar role, especially in the growth of low-carbon energy sources in emerging Asia as it was. Generation from renewables is expected to exceed 7600 TWh by 2021. Over the next five years, renewables will remain the fastest-growing source of electricity generation, with their share growing to $28 \%$ in 2021 from $23 \%$ in 2015 [45]. Notably, it makes an impressive remark that almost half a million solar panels were installed worldwide every day last year. Certainly, last year has been a turning point for renewables, but there is still proof that it continues on renewable growth for the transportation and for heat sectors to remain weak and in need of even stronger government efforts.

2.2. Concentrating Solar Power System (CSP). CSP is a mechanism of enhancing solar power density and delivering electricity and thermal power. Using different mirror configurations, CSP generates electric power by transforming the solar energy into high-temperature warmth; thereby, a typical generator is utilized for channeling the heat [46]. Plants contain two parts: one that harvests and transforms solar power into heat and the other that produces electricity from heating energy. CSP for the village is $10 \mathrm{~km} / \mathrm{w}$, and for the grid, applications may be scaled up to 100 megawatts [47]. During cloudy hours or at night, some devices have thermal storage available. Other elements can be paired with gas, and hybrid power stations will have dispatchable hybrid power. For thousands of years, CSP has been perceived and recognized by inventors. The origin of the current solar focus is believed to be in the seventeenth century. In the early 20th century, several new projects for concentrating varied from solar pumps to steam power turbines to distilling water. Concentrated solar (CS) technology is categorized into two distinct types, and they are shown in Figure 7. Tracking CS and nontracking are the two technologies of CSP.

There are four primary tracking CS technologies such as parabolic trough, solar tower, linear Fresnel reflectors, and parabolic dish defined based on the radius and technical treatment of the sun which are shown in Figure 8. Parabolic troughs are the most evolved CS methods and comprise most existing commercial plants. The parabola trough is the linear fixation collector composed of a cylindrically curved parabola mirror, reflecting the sunlight of a tube in the parabola focal line [48]. The tubular receiver comprises the heat-absorbing liquid and passes it into the furnace or other steam-making system through the circulation. The linear Fresnel reflector includes the FLR mirror tracking phase, which concentrates solar-based beam radiation onto a receiver tube mounted on the focal point of the Fresnel mirror and produces high-temperature working media to produce thermal cycle power [49]. Sunshine is converted into renewable energy by solar power towers. Many large heliostats are used to concentrate the sunlight on a receiver over a tower [50].
Parabolic-dish solar concentrators are two-axis solar tracking systems focusing solar radiation onto the heat receiver at the center point of the platform collector $[52,53]$. The technical specifications of these four CS technologies are illustrated in Table 1. The capacity, implementation status, and operating year are discussed in the table. The parabolic dish Stirling tracking CS technology is installed in the outer environment, and it been operating from 1986 with a capacity of $10-25 \mathrm{~kW}$.

\section{Thermal Energy Storage}

The attributable benefits of CSP innovations are achieved through the incorporation of traditional heat plants. A carbon burner is incorporated in conventional thermal cycles by thermal storage solar heat plants which can offer firm capabilities without needing to build separate backup power plants and without stochastic grid disturbance [55, 56]. Trough designs can incorporate thermal storage setting aside the heat transfer fluid in its hot phase allowing for electricity generation several hours into the evening [57]. All parabolic trough plants for this study are hybrids, meaning they use fossil fuel to supplement the solar output during periods of low solar radiation. Typically, a natural gas-fired heat or a gas steam boiler/preheater is used; troughs also can be integrated with existing coal-fired plants. The reflector follows the sun during the daylight hours by tracking along a single axis. A working fluid is heated to $150-350 \mathrm{oc}$ as it flows through the receiver and then utilized as a heat source for a power generation system. The complete mechanism of the power generation is shown in Figure 9.

The Archimedes scheme integrates the best technologies of today with today's solar field, a storage facility, and a steam engine, the first of its kind in the world to be unveiled in Italy on 15 July 2010 [58]. Solar energy is stored in 360 linear parabolic collectors in the modular solar region. To optimize the working temperature and the capacity to store heat, the Italian National Agency for New Technologies, Energy and Sustainable Economic Development (ENEA), has unveiled a novel fluid heat carrier. The new concept of a concentrator based on thinner mirrors is another creative aspect of ENEA, saving building and installation expenses [59]. The utilization of ample heat storage enables the plant to heat the steam generator 24 hours a day at a uniform frequency regardless of the fluctuations in solar power availability. The steam generator includes heat exchangers "tube and shell" in which heat is transported to water to form superheated steam to be used in conventional thermoelectric plants. $5 \mathrm{MW}$ solar plant worth almost $€ 60$ million has a specific characteristic to capture and store the solar thermal energy for several hours, allowing both off-sunshine and overcast sky power to be produced by the plant [60]. It is factual that the 2100 tonnes of oil saved and carbon dioxide emissions cut by 3250 tonnes over one year. The current findings represent a significant achievement, costing approximately five or six times more for the kilowatt-hour produced about the energy costs extracted using traditional fuels [10]. Access to large volumes of water is a significant obstacle for CSP use in arid areas because the water supplies 


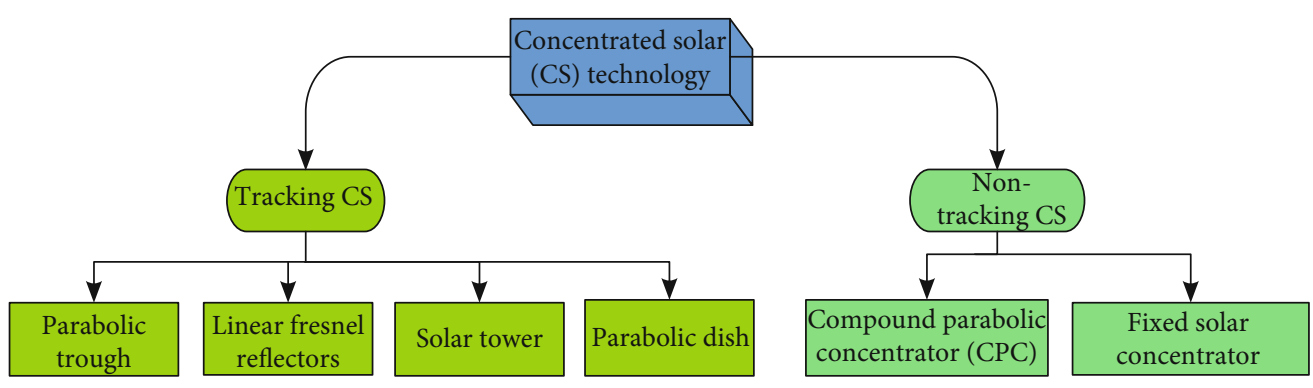

FIgURE 7: Concentrating solar technology.

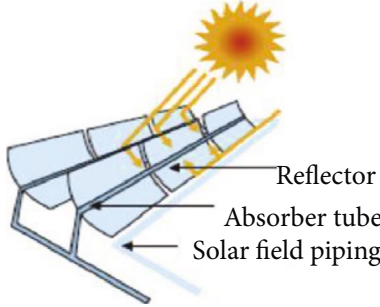

(a)

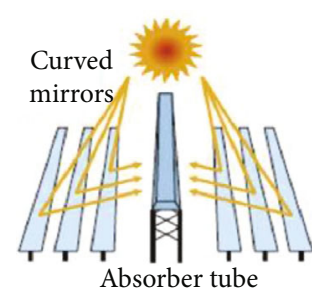

and reconcentrato

(c)

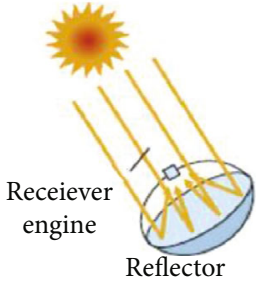

(b)

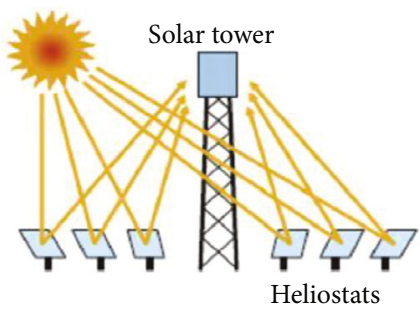

(d)

Figure 8: (a) Parabolic trough. (b) Dish Stirling. (c) Linear Fresnel reflectors. (d) Solar tower [51].

TABLe 1: Details of tracking CS [54].

\begin{tabular}{lccc}
\hline Tracking CS & Capacity & Status & Operating \\
\hline Parabolic trough & $50-200 \mathrm{MW}$ & Proven utility-scale technology & 1984 \\
Liner Fresnel reflectors & $50-200 \mathrm{MW}$ & In development & 2012 \\
Solar tower & $50-100 \mathrm{MW}$ & Demo plants built & 2007 \\
Parabolic dish Stirling & $10-25 \mathrm{~kW}$ & Installation & 1986 \\
\hline
\end{tabular}

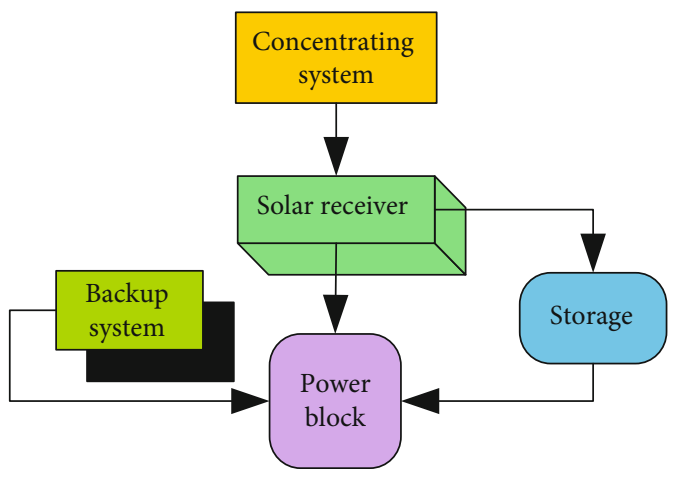

Figure 9: Process of thermal energy storage. available are widely regarded by many stakeholders. Dry air cooling is a powerful alternative used in North Africa on the ISCC plants under development. However, it is more costly and reduces productivity. When installed in hot desert trough plants, it tends to decrease the annual production of energy by $7 \%$ and elevates the cost of electricity generated by approximately $10 \%$. For solar towers, the efficiency penalty is less than for parabola dry cooling. Solar process heat promises an exciting future for the solar thermal industry, the need for industrial process heat is enormous, and many demonstration systems are fully operational. It is a technology ready for deployment and well-identified in the sector and the primary trend in research and development. Exceptionally, a medium-size solar process heating plant should be engineered, and feasibility analysis was undertaken out so 


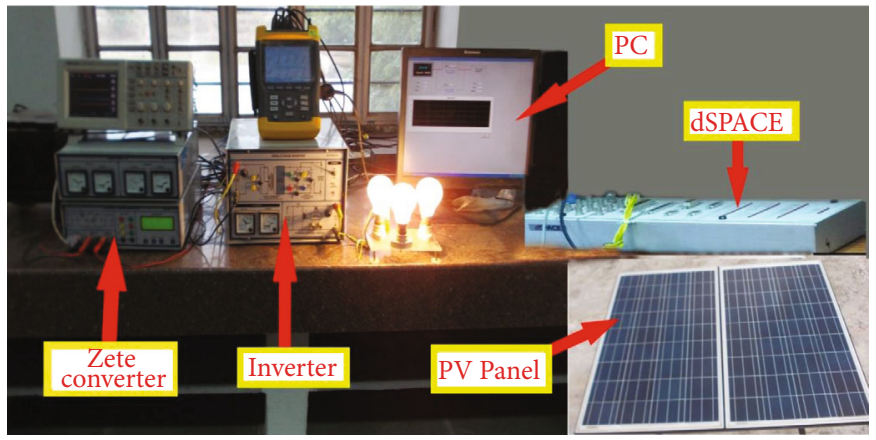

Figure 10: Hardware developed to set up in the laboratory.

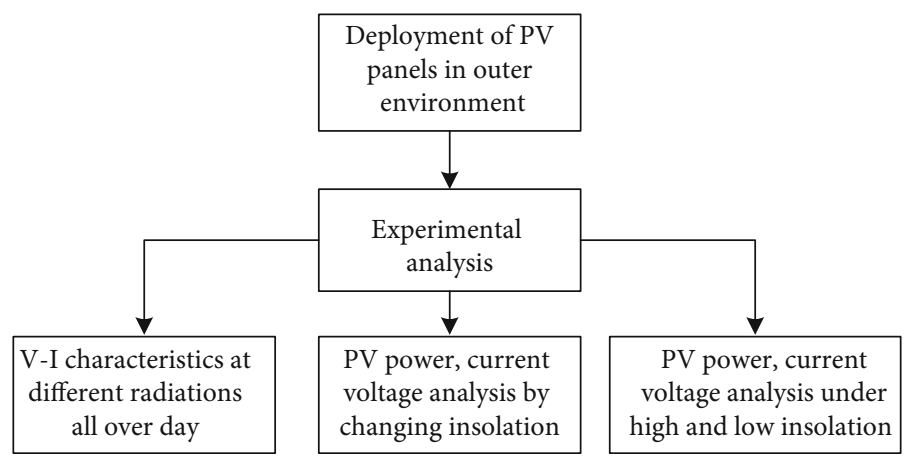

FIGURE 11: Flow chart of the proposed system.

that the graduates can realize the position of a system developer or an engineer in the industry.

\section{Discussion}

4.1. The Gap between PV and CSP Development. The CSP method operates only for irradiance, whereas the diffuse radiation can also be used for $\mathrm{PV}$ systems. The PV can then be mounted anywhere, while the required CSP areas are far more limited. PV plants will have opportunities for a dispersed and decentralized generation while CSP plants do not scale down well, and CSP production needs to provide a transmission grid. The photovoltaic system is primarily about solar panels, and CSP power plants incorporate a significant number of critical mechanical and chemical components. CSP plants require equal to 10 acres per MW, while crystalline technology needs around 4.5-5 acres of area for $1 \mathrm{MW}$ of electricity, and thin-film technology requires about 6.5-7.5 hectares [61]. It is only an approximate criterion that can differ depending on panel technology and performance. In terms of materials, CSP plants demand a significant level of iron and cement. In contrast, in their manufacturing phase, PV plants need essential materials such as indium and rare earth elements.

In small-scale systems, the construction cost for photovoltaic plants is about 2,000-2,500 EUR/kW, and the price for the larger ones is just $1500 \mathrm{EUR} / \mathrm{kW}$ [62]. It is important to remember that, for both utility (MW-scale) and industrial (kW-scale) plants, the average cost of PV plants has been declining over the last few years, with a much less price decline to come in the future forecast. The infrastructure costs for CSP plants vary from 2,000-6,000 EUR/kW, depending on the technology, size, and potential usage of the heat storage facility. Ordinary annual operating costs for the photovoltaics plant are equivalent to $1 \%$ of initial expenditure compared with around 20/0 for CSR energy depletion. Moreover, the entire life span of the installation (ranging from 0.5 to $1 \%$ each year) has minor economic consequences for the CSP plant than for the PV plant. CSP generates more electricity than PV plants with the same rated capacity and the same environmental conditions. It demonstrates that the CSP's economic return is more substantial. PV systems are now the world's most common solar electric technologies.

At the end of 2015 , over $235 \mathrm{GW}$ of photovoltaic power systems had been installed worldwide, while there are now fewer than five GW of CSP technology [63]. Yet, this global CSP capacity is projected to reach up to $22 \mathrm{GW}$ by 2025 with $1.2 \mathrm{GW}$ of newly added capacity and a turnaround in activities shortly [64]. A few of the benefits of the CSP device are likely the conservation of heat. Power supply at peak time is an essential and demanding factor of power plant projects. As an intermediate phase to produce electricity over peak hours, CSP system provides the capacity to provide quick, reliable, and environmental storage of heat energy. Distinct technologies allow thermal storage for use in CSP systems. The second significant aspect is some possible technological transformations that might intensify CSP production in the area of "solar fuels." When comparing the CSP trend with the other sources of renewable energy, we can see that CSP 


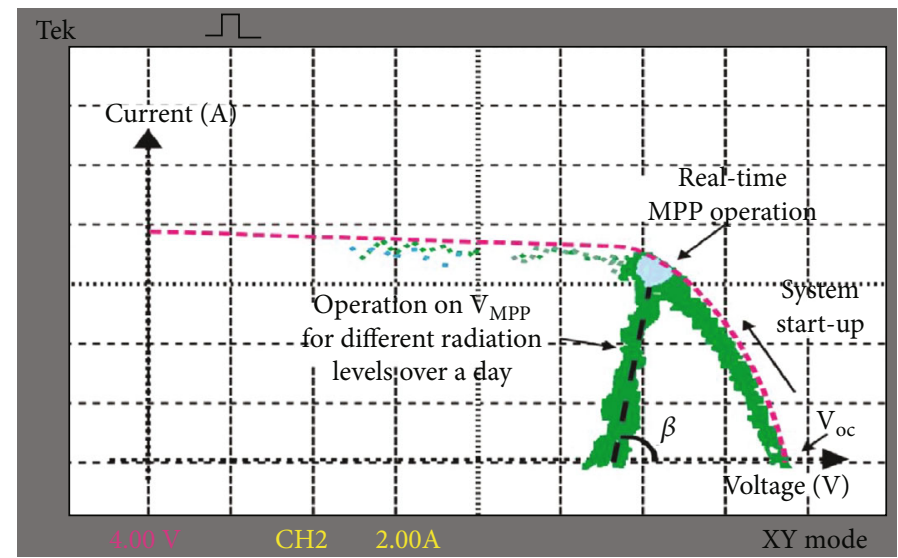

FIGURE 12: I-V characteristics under maximum power point condition.

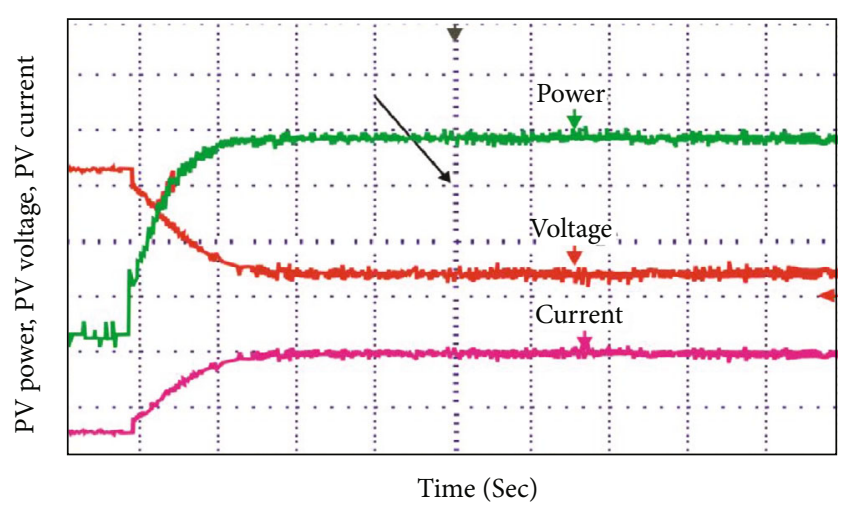

Figure 13: Practical obtained responses in changing solar insolation.

is at a significant shift. The initial and operational effect of CSP schemes would undoubtedly have a considerable impact on mirrors, vacuum receivers, optics, support systems, efficient heat transfer fluid, and turbines. CSP systems could provide about 10 percent of world energy in the most favorable circumstance [65]. The mass manufacturing of photovoltaic systems and public subsidies culminated in the development of low cost-effective multifunctional cells. In short, one technology cannot be claimed to be superior to another. Here, we tried to illustrate those problems that must be weighed before determining which solar energy is the best for a given situation.

Figure 10 illustrates an implementation of the PV system with dSPACE controller to check the power, voltage, and current characteristics under different irradiations. The flow chart of the proposed system is shown in Figure 11. The PV panel is deployed in the outer environment; the voltage obtaining from the PV is powered to the bulbs. The power to the bulb is provided by inverting the voltage obtaining from PV. The zeta converter can convert input voltage into a noninverted output voltage that might be lower or greater than the input voltage.

The system starts with maximum open-circuit voltage $\left(V_{\mathrm{oc}}\right)$ to account the real-time maximum power point operation (MPP) with varying I-V characteristics as represented

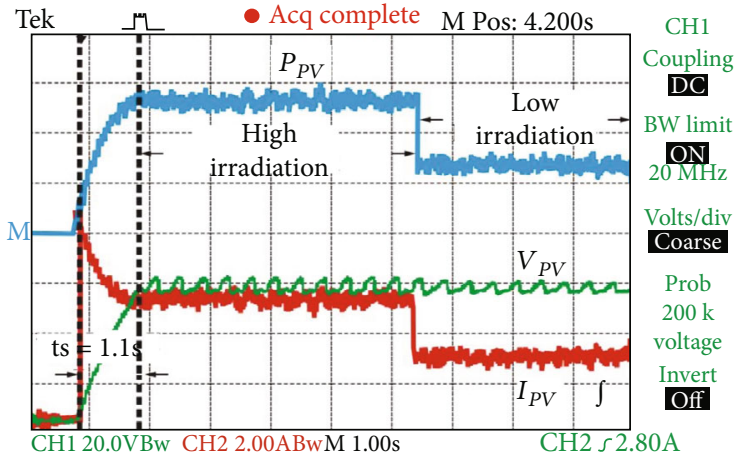

FIgURe 14: Practical results under high and low sun insolation conditions.

by the pink dotted line (Figure 12). Further, the black dotted line represents the I-V characteristics of the solar cell operated at maximum power point voltage $\left(V_{\mathrm{MPP}}\right)$ for different radiation levels over a day. The variation in current with respect to voltage is demonstrated by an angle $(\beta)$. Figure 13 describes the actual functioning of the solar cell (respective to power, voltage, and current parameters) upon irradiation. It is visible that with increasing irradiation time, the voltage across the cell decreases with increasing current and further becomes constant confirming the accurate behavior of the solar system.

The practical current responses of the proposed PV system under low and high sun insolation have been realized at obtained constant voltage as shown in Figure 14. It is observed that the exhibited current is higher at high irradiation compared to low irradiation. Hence, higher power is gained at high irradiation. Payback analysis, net benefit analysis, saving-to-investment ratio, adjusted internal rate of return, and life-cycle cost analysis are five economic analysis parameters that are frequently used for solar PV plant placement. Currently, in this study, the proposed system is shown as proof of concept for showing significance of the PV system for electricity generation. In the future, the proposed system will be deployed in a wide range and the economic aspects of the system will be evaluated in detail. 


\section{Conclusion}

The UNDP set a target of comprehensive implementation of renewable energy sources for minimizing the impact of carbon emissions on the environment. Renewable energy sources have the potential to generate sustainable electricity for all. Solar energy is one of the prominent renewable energies that is generated through the radiation of the sun. At present, solar energy is widely implemented in many countries to meet the electricity demand sustainably. PV and CSP are the two different technologies utilized to capture the heat generated from the sun. This article presents the mechanism, types, and advancement of PV and CSP technology concerning the widely implemented technologies in many countries for electricity generation. Thermal energy storage is one of the prominent technologies utilized for storing the heat energy obtained through CSP. A gap between the PV and CSP technologies is presented in the article to enhance the performance. As part of the proof of concept, an experiment is carried with PV panels in the outer environment. The power, current, and voltage analysis of the suggested system are evaluated in this experiment, and it is found that the observed current is higher at high irradiation relative to low irradiation. In the future scope, PV and CSP technologies play a crucial role for the generation of renewable power in a sustainable manner that minimizes impact on the environment.

\section{Data Availability}

Data will be available on request. For the data-related queries, kindly contact Vinod Kumar Sharma (vinodkumar.swarma@enea.it).

\section{Conflicts of Interest}

The authors declare that they have no conflicts of interest.

\section{References}

[1] A. Nandi and V. K. Kamboj, "A new solution to profit based unit commitment problem considering PEVs/BEVs and renewable energy sources," in E3S Web of Conferences, p. 8, Punjab, India, 2020.

[2] P. Verma, H. Bedi, and R. K. Sharma, Integrated utilization of solar energy in a zero energy building (ZEB): an approach towards sustainable development, International Science Press, Phagwara, India, 2016.

[3] A. Churasia, J. Singh, and A. Kumar, "Production of biodiesel from soybean oil biomass as renewable energy source," Journal of Environmental Biology, vol. 37, no. 6, pp. 1303-1307, 2016.

[4] P. A. Owusu and S. Asumadu-Sarkodie, "A review of renewable energy sources, sustainability issues and climate change mitigation," Cogent Engineering, vol. 3, no. 1, article 1167990, 2016.

[5] "Energy projections, calculating long term energy demand |IAEA," November 2021, https://www.iaea.org/topics/energyprojections.
[6] Z. Hausfather and J. Ritchie, "A 3C world is now "business as usual, The Breakthrough Institute,” November 2021, https:// thebreakthrough.org/issues/energy/3c-world.

[7] V. Suresh, S. Sreejith, S. K. Sudabattula, and V. K. Kamboj, "Demand response-integrated economic dispatch incorporating renewable energy sources using ameliorated dragonfly algorithm," Electrical Engineering, vol. 101, no. 2, pp. 421$442,2019$.

[8] M. Sharma, J. Singh, C. Baskar, and A. Kumar, "A comprehensive review of renewable energy production from biomassderived bio-oil," BioTechnologia. Journal of Biotechnology Computational Biology and Bionanotechnology, vol. 100, no. 2, pp. 179-194, 2019.

[9] M. L. Mittal, "Estimates of emissions from coal fired thermal power plants in India," in 2012 International emission inventory conference, pp. 1-22, New Delhi India, 2010.

[10] L. Abdallah and T. El-Shennawy, "Reducing carbon dioxide emissions from electricity sector using smart electric grid applications," Journal of Engineering, vol. 2013, Article ID 845051, 8 pages, 2013.

[11] "Climate change indicators: atmospheric concentrations of greenhouse gases, Climate Change Indicators in the United States, US EPA," December 2021, https://www.epa.gov/ climate-indicators/climate-change-indicators-atmosphericconcentrations-greenhouse-gases.

[12] P. Talebizadeh, M. A. Mehrabian, and H. Rahimzadeh, "Optimization of heliostat layout in central receiver solar power plants," Journal of Energy Engineering, vol. 140, no. 4, article 4014005, 2014.

[13] A. H. Eisapour, M. Eisapour, M. J. Hosseini, A. H. Shafaghat, P. Talebizadeh Sardari, and A. A. Ranjbar, "Toward a highly efficient photovoltaic thermal module: energy and exergy analysis," Renewable Energy, vol. 169, pp. 1351-1372, 2021.

[14] M. Eisapour, A. H. Eisapour, M. J. Hosseini, and P. Talebizadehsardari, "Exergy and energy analysis of wavy tubes photovoltaic-thermal systems using microencapsulated PCM nano-slurry coolant fluid," Applied Energy, vol. 266, article 114849, 2020.

[15] R. Singh, S. Kumar, A. Gehlot, and R. Pachauri, “An imperative role of sun trackers in photovoltaic technology: a review," Renewable and Sustainable Energy Reviews, vol. 82, pp. 32633278, 2018.

[16] D. Dhawale and V. K. Kamboj, "Scope of intelligence approcahes for unit commitment under uncertain sustainable energy environment for effective vehicle to grid operations-a comprehensive review," in E3S Web of Conferences, p. 1034, India, 2020

[17] O. Bamisile, S. Obiora, Q. Huang et al., "Towards a sustainable and cleaner environment in China: dynamic analysis of vehicle-to-grid, batteries and hydro storage for optimal RE integration," Sustainable Energy Technologies and Assessments, vol. 42, article 100872, 2020.

[18] "The biggest solar power plants in the world," https://www .power-technology.com/features/the-worlds-biggest-solarpower-plants/.

[19] "World Energy Outlook 2017 analysis - IEA," https://www.iea .org/reports/world-energy-outlook-2017.

[20] X. Ju, C. Xu, Y. Hu, X. Han, G. Wei, and X. Du, "A review on the development of photovoltaic/concentrated solar power (PV-CSP) hybrid systems," Solar Energy Materials \& Solar Cells, vol. 161, pp. 305-327, 2017. 
[21] D. Gielen, F. Boshell, D. Saygin, M. D. Bazilian, N. Wagner, and R. Gorini, "The role of renewable energy in the global energy transformation," Energy Strategy Reviews, vol. 24, pp. 38-50, 2019.

[22] W. Palz, "Power for the world: the emergence of electricity from the Sun," Pan Stanford Publishing, 2021, https://www .routledge.com/Power-for-the-World-The-Emergence-ofElectricity-from-the-Sun/Palz/p/book/9789814303378.

[23] J. C. R. Kumar and M. A. Majid, "Renewable energy for sustainable development in India: current statusfuture prospects challenges employment and investment opportunities," Energy Sustainability and Society, vol. 10, no. 1, pp. 1-36, 2020.

[24] M. Sharma, K. Bansal, and D. Buddhi, "Real time data acquisition system for performance analysis of modified PV module and derivation of cooling coefficients of electrical parameters," Procedia Computer Science, vol. 48, pp. 582-588, 2015.

[25] M. Sharma, K. Bansal, and D. Buddhi, "Operating temperature of PV module modified with surface cooling unit in real time condition," in 2014 IEEE 6th India International Conference on Power Electronics (IICPE), Kurukshetra, India, 2015.

[26] “Global new installed solar PV capacity 2019 Statista," https:// www.statista.com/statistics/280200/global-new-installedsolar-pv-capacity/.

[27] “LCOE \& competitiveness - ETIP PV.," https://etip-pv.eu/ about/working-groups/lcoe-competiveness/.

[28] Market Report Series: Renewables 2017 analysis - IEAhttps:// www.iea.org/reports/renewables-2017.

[29] T. S. Ustun, Y. Nakamura, J. Hashimoto, and K. Otani, "Performance analysis of PV panels based on different technologies after two years of outdoor exposure in Fukushima, Japan," Renewable Energy, vol. 136, pp. 159-178, 2019.

[30] X. Su, Q. Wu, J. Li et al., "Silicon-based nanomaterials for lithium-ion batteries: a review," Advanced Energy Materials, vol. 4, no. 1, article 1300882, 2014.

[31] J. Ramanujam and U. P. Singh, "Copper indium gallium selenide based solar cells - a review," Energy and Environmental Science, vol. 10, no. 6, pp. 1306-1319, 2017.

[32] T. D. Lee and A. U. Ebong, "A review of thin film solar cell technologies and challenges," Renewable and Sustainable Energy Reviews, vol. 70, pp. 1286-1297, 2017.

[33] N. Kannan and D. Vakeesan, "Solar energy for future world: - a review," Renewable and Sustainable Energy Reviews, vol. 62, pp. 1092-1105, 2016.

[34] S. Almosni, A. Delamarre, Z. Jehl et al., "Material challenges for solar cells in the twenty-first century: directions in emerging technologies," Science and Technology of Advanced Materials, vol. 19, no. 1, pp. 336-369, 2018.

[35] O. Chernyak, Y. Chernyak, and Y. Fareniuk, "Forecasting of global new investment in renewable energy," HAICTA, vol. 2030, pp. 272-278, 2017.

[36] "Solar PV module manufacturing base continues to consolidate in 2020 IHS Markit," https://ihsmarkit.com/researchanalysis/solar-pv-module-manufacturing-base-continuesconsolidate-2020.html.

[37] E. Vartiainen, G. Masson, C. Breyer, D. Moser, and E. Román Medina, "Impact of weighted average cost of capital capital expenditure and other parameters on future utility-scale PV levelised cost of electricity," Progress in Photovoltaics: Research and Applications, vol. 28, no. 6, pp. 439-453, 2020.
[38] "Solar photovoltaic electricity solar generation 6 solar photovoltaic electricity," European Photovoltaic Industry Association-EPIA, 2011.

[39] E. Hannah, M. Duncan, and G. T. André, "Renewables 2019 Global Status Report,” December 2021, https://www.ren21 .net/gsr-2019/.

[40] A. Blakers, N. Zin, K. R. Mcintosh, and K. Fong, "High efficiency silicon solar cells," Energy Procedia, vol. 33, pp. 1-10, 2013.

[41] G. Persen, How do the EU's climate and energy policies affect Norwegian electricity prices and the outlook for profitable wind power development in 2030? [M.S. thesis], Norwegian School of Economics, Supervisor Linda Nøstbakken, Bergen, Spring, 2017.

[42] “(18) Semiconductor industry steps into the solar PV market Request PDF," https://www.researchgate.net/publication/ 297781288_Semiconductor_industry_steps_into_the_solar_ PV_market.

[43] M. Woodhouse, B. Smith, A. Ramdas, and R. Margolis, Crystalline silicon photovoltaic module manufacturing costs and sustainable pricing: 1H 2018 benchmark and cost reduction roadmap, National Renewable Energy Lab.(NREL), Golden, CO (United States), 2019.

[44] M. GREEN, "Solar cell efficiency tables (version 40)," IEEE Transactions on Fuzzy Systems, vol. 20, no. 6, pp. 1114-1129, 2012.

[45] "IEA raises its five-year renewable growth forecast as 2015 marks record year - news - IEA," https://www.iea.org/news/ iea-raises-its-five-year-renewable-growth-forecast-as-2015marks-record-year.

[46] M. Mehos, Concentrating Solar Power Gen3 Demonstration Roadmap, Golden, CO (United States), 2017.

[47] "Concentrating Solar Power Technology: Principles, Developments and Applications - Google Books," https://books.google .co.in/books?hl=en\&lr=\&id=V6NgAgAAQBAJ\&oi=fnd\&pg= $\mathrm{PP} 1 \& \mathrm{dq}=$ concentrating + solar + power+technology \&ots= nugR3aP40D\&sig=ilWdCW7PHRmB7Z1uZeu4oehf3Os\#v= onepage\&q=concentrating solar power technology\&f=false..

[48] G. K. Manikandan, S. Iniyan, and R. Goic, "Enhancing the optical and thermal efficiency of a parabolic trough collector - a review," Applied Energy, vol. 235, pp. 1524-1540, 2019.

[49] M. Alhaj, A. Mabrouk, and S. G. Al-Ghamdi, "Energy efficient multi-effect distillation powered by a solar linear Fresnel collector," Energy Conversion and Management, vol. 171, pp. 576-586, 2018.

[50] R. Chen, Z. Rao, and S. Liao, "Determination of key parameters for sizing the heliostat field and thermal energy storage in solar tower power plants," Energy Conversion and Management, vol. 177, pp. 385-394, 2018.

[51] Y. Zhao, A. Dunn, J. Lin, and D. Shi, Photothermal Effect of Nanomaterials for Efficient Energy Applications, Elsevier Inc., 2018.

[52] R. D. Jilte, J. K. Nayak, and S. B. Kedare, "Experimental investigation on heat losses from differentially heated cylindrical cavity receiver used in paraboloid concentrator," Journal of Solar Energy Engineering, vol. 139, no. 3, 2017.

[53] L. G. Pheng, R. Affandi, M. R. Ab Ghani, G. C. Kim, and Z. Zano, "Study the feasibility of Parabolic Dish (PD) from several prospective criteria in Malaysia environment," Journal of Engineering and Applied Science, vol. 11, no. 6, pp. 39293937, 2016. 
[54] H. L. Zhang, J. Baeyens, J. Degrève, and G. Cacères, "Concentrated solar power plants : review and design methodology," Renewable and sustainable energy reviews, vol. 22, pp. 466481, 2013.

[55] D. Wendt, H. Huang, G. Zhu et al., "Geologic thermal energy storage of solar heat to provide a source of dispatchable renewable power and seasonal energy storage capacity," GRC Transactions, vol. 43, pp. 73-91, 2019.

[56] D. Buddhi, R. Kumar, and R. Singh, "Thermal energy management in textile industries," vol. 5, no. 4, pp. 438-450, 2018.

[57] A. Häberle, Concentrating solar technologies for industrial process heat and cooling In Concentrating Solar Power Technology, Woodhead Publishing, 2012.

[58] A. Maccari, D. Bissi, G. Casubolo et al., "Archimede solar energy molten salt parabolic trough demo plant: a step ahead towards the new frontiers of CSP," Energy Procedia, vol. 69, pp. 1643-1651, 2015.

[59] A. Castaldo, G. Vitiello, E. Gambale, M. Lanchi, M. Ferrara, and M. Zinzi, "Mirroring solar radiation emitting heat toward the universe: design, production, and preliminary testing of a metamaterial based daytime passive radiative cooler," Energies, vol. 13, no. 16, p. 4192, 2020.

[60] J. J. C. S. Santos, J. C. E. Palacio, A. M. M. Reyes, M. Carvalho, A. J. R. Freire, and M. A. Barone, "Concentrating solar power," Adv. Renew. Energies Power Technol., vol. 1, no. 2, pp. 373402, 2018.

[61] "How much land is required for solar PV farms," http://www .solarmango.com/ask/2015/10/09/how-much-land-isrequired-for-solar-pv-farms/.

[62] “JRC Science for Policy Report, 2019," November 2021, https://ec.europa.eu/jrc/sites/default/files/pesetaiv_summary_ final_report.pdf.

[63] K. Mohammadi and H. Khorasanizadeh, "The potential and deployment viability of concentrated solar power (CSP) in Iran," Energy Strategy Reviews, vol. 24, pp. 358-369, 2019.

[64] A. K. Singh and A. H. Idrisi, "Evolution of renewable energy in India: wind and solar," Journal of The Institution of Engineers (India): Series C, vol. 101, no. 2, pp. 415-427, 2020.

[65] A. Bielecki, S. Ernst, W. Skrodzka, and I. Wojnicki, "Concentrated solar power plants with molten salt storage: economic aspects and perspectives in the European Union," International Journal of Photoenergy, vol. 2019, Article ID 8796814, 10 pages, 2019. 